University of Nebraska - Lincoln

DigitalCommons@University of Nebraska - Lincoln

USGS Staff - Published Research

US Geological Survey

2017

Extending the Habitat Concept to the Airspace

Robert H. Diehl

Northern Rocky Mountain Science Center, rhdiehl@usgs.gov

Anna C. Peterson

University of Minnesota, Saint Paul, Pete1112@umn.edu

Rachel T. Bolus

SouthernUtah University, rachelbolus@suu.edu

Douglas Johnson

Northern Prairie Wildlife Research Center, Douglas_H_Johnson@usgs.gov

Follow this and additional works at: https://digitalcommons.unl.edu/usgsstaffpub

Part of the Geology Commons, Oceanography and Atmospheric Sciences and Meteorology Commons, Other Earth Sciences Commons, and the Other Environmental Sciences Commons

Diehl, Robert H.; Peterson, Anna C.; Bolus, Rachel T.; and Johnson, Douglas, "Extending the Habitat Concept to the Airspace" (2017). USGS Staff -- Published Research. 1129.

https://digitalcommons.unl.edu/usgsstaffpub/1129

This Article is brought to you for free and open access by the US Geological Survey at DigitalCommons@University of Nebraska - Lincoln. It has been accepted for inclusion in USGS Staff -- Published Research by an authorized administrator of DigitalCommons@University of Nebraska - Lincoln. 


\title{
Extending the Habitat Concept to the Airspace
}

\author{
Robert H. Diehl, Anna C. Peterson, Rachel T. Bolus, \\ and Douglas $\mathrm{H}$. Johnson
}

\begin{abstract}
Habitat is one of the most familiar and fundamental concepts in the fields of ecology, animal behavior, and wildlife conservation and management. Humans interact with habitats through their senses and experiences and education to such a degree that their perceptions of habitat have become second nature. For this reason, it may be difficult at first to accept the airspace as habitat, an area that is invisible, untouchable, highly dynamic, and its occupants difficult to see. Nonetheless, the habitat concept, by definition and in practice, applies readily to the airspace. Some ecological and behavioral processes including habitat selection, foraging, and reproduction are operational in the airspace, while others, particularly those mediated by resource limitation such as territoriality, are likely uncommon if present at all. The behaviors of flying animals increasingly expose them to anthropogenic hazards as development of the airspace accelerates. This exacerbates the need to identify approaches for managing these human-wildlife conflicts in aerial habitats, especially where human safety or at-risk populations are concerned. The habitat concept has proven useful in shaping environmental law and policy to help
\end{abstract}

\footnotetext{
R.H. Diehl $(\bowtie)$

US Geological Survey, Northern Rocky Mountain Science Center, Bozeman, MT, USA e-mail: rhdiehl@usgs.gov
}

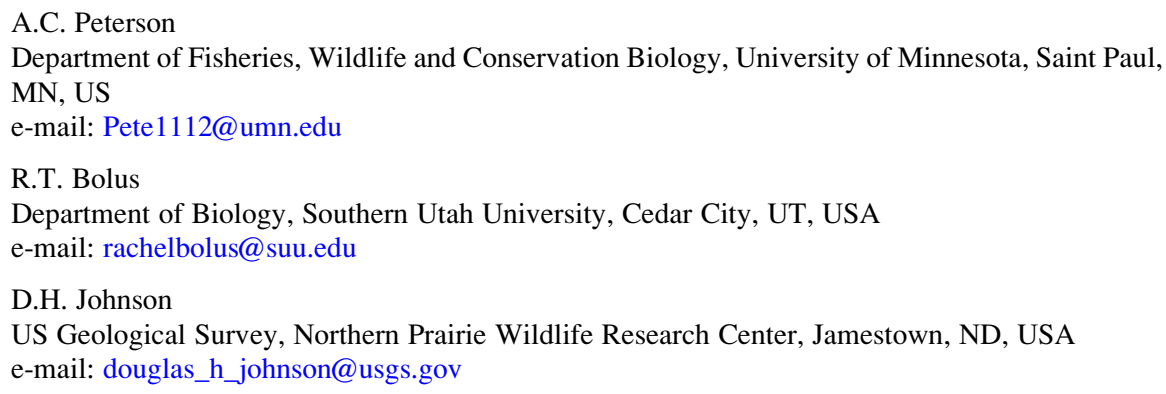


mitigate these conflicts. It remains to be seen whether current law can bend to include a more expansive concept of habitat that includes the airspace.

1 What Is Habitat?

Consider an organism moving through a vast and apparently featureless yet dynamic fluid medium. Its behavioral and physical phenotype is designed for life in this medium, and its survival contingent upon its ability to seek out favorable currents in which to move about, find food, sleep, and avoid predators. This might describe the rudimentary natural history of countless pelagic fish species and we would not hesitate to call the open water they occupy a habitat. This might also describe the natural history of numerous bird species and the airspaces they occupy, yet most would claim a bird in flight is not in habitat. The notion of habitat is firmly linked to terrestrial or aquatic places, yet nothing about the ecology of habitats excludes the airspace which shares many ecological parallels with its terrestrial and aquatic counterparts.

Ecologists have struggled to define habitat. Linnæus (1754), his mind on plants, informally referred to "the native places" (where one finds a given species of plant) as "station," his nascent term for habitat. This concept was developed with principles that apply to sessile plants and which have continued to influence scientific understanding of habitat; however, highly mobile organisms defy our attempts to discretely categorize their habitats by plant communities (e.g., forest, grassland) and/or geological formations (e.g., river, alpine). Linnæus' general perception of habitat remains widely accepted today, even as a persistent dissatisfaction surrounds a precise definition. Odum's (1959) definition of habitat as "the place an organism lives, or where one would go to find it" is perhaps the most familiar to ecologists. A few years later, perhaps dissatisfied with this and other definitions, Elton (1966) stated that, "definition of habitat, or rather lack of it, is one of the chief blind spots in zoology," and efforts to define it continue. Many of the more generalizable definitions of habitat offer some reference to occupancy or resources that promote occupancy (e.g., Hall et al. 1997; Dennis et al. 2003, 2006; Morrison et al. 2006). Of these, Morrison et al.'s is among the more precise and generalizable, calling habitat an "area with a combination of resources and environmental conditions that promotes occupancy by individuals of a given species that allows individuals to survive and reproduce." More context specific definitions usually involve additional criteria and represent special cases and are therefore less broadly applicable to the life history of organisms as a whole (e.g., by requiring the presence of vegetation). The airspace satisfies criteria set forth in these and other broadly defined conceptions of habitat in that it contains resources that promote occupancy. These include food, mates, opportunities to avoid predators, and a low friction, relatively uncluttered medium enabling efficient travel. The idea that the airspace should be considered habitat (Diehl 2013) is gaining acceptance and is a fundamental tenet of the emerging field of aeroecology (Kunz et al. 2008). 
It was unclear how long airborne resources could sustain life during flight, particularly of a vertebrate, until Alpine and Common Swifts (Tachymarptis melba and Apus apus) were documented remaining aloft for several months without landing (Liechti et al. 2013; Hedenström et al. 2016). The airspace alone provided all the resources required to sustain the swift's biology, including food and sleep. Much as a terrestrial amphibian uses the water only to breed, these swifts appear to need land only to support their nests and eggs. (The word "amphibious" means "leading a double life" in Greek, and had early taxonomists not applied this word exclusively to animals that exist between the land and water, we might also label swifts as "amphibious.") In addition, recent research shows that the microscopic biological flotsam of the air is composed not only of inert cells and bits of feathers but also of life: pollen, bacteria, fungi, and protists (Deprés et al. 2012). The airspace is teeming with microbial communities that spend generations aloft before settling back to the surface after metabolizing, undergoing selection, and reproducing (Womack et al. 2010). Such phenomena challenge biologists to accept that the airspace is habitat. The alternative - that such organisms are sustained through large proportions of their lives outside habitat—suggests that the current habitat model be rejected altogether, although it is unclear what might replace it (Dennis et al. 2003). A revised understanding of habitat that includes the airspace offers a new context to consider the habitat concept. Relative to its terrestrial and aquatic counterparts, the airspace is highly dynamic yet presumably lacking in much of the structure and organizational complexity that comes with higher plant and animal abundances, species diversity, and physical substrates typically associated with habitat.

Despite a strong ecological basis that the airspace should be considered habitat, the notion remains counterintuitive and references to the airspace as habitat are vague where they exist at all (e.g., Cadenasso et al. 2003). Through formal education and personal experience, we learn about habitat strictly in terms of land and water. Indeed, among all vertebrates and macroinvertebrates, humans and a relative handful of other species are actually unusual for their inability to fly. Our perceptions shape how we understand and apply the habitat concept in ways that may have consequences for wildlife conservation and management and the education of future generations.

Early hunter-gatherer societies likely cultivated a deep understanding of the natural history of plants and animals, so the awareness of habitat (in the sense that certain resources can be found in certain places at certain times) predates scientific recognition and definition by millions of years. The knowledge of when and where to gain access to resources was critical to survival throughout evolutionary history and therefore linked to resources that were accessible (that is, by land and water, but seldom through the air). As such, perceptions of habitat may be deeply ingrained, possibly even codified in our DNA, and indeed, a genetic basis for habitat preference is well documented among some species (Jaenike and Holt 1991).

Evolution shaped our senses for survival on land and water to a degree that almost certainly influences our perceptions of what constitutes habitat, so considering the airspace as a habitat poses several challenges. The airspace is largely 
invisible as are many of the features that give it structure (e.g., wind, temperature, pressure, geomagnetism). Even those features which are detectable to humans through nonvisual channels (e.g., wind) likely do not carry the same meaning as they do with flying animals. We lack certain sensory receptive organs (e.g., cilia) and the neurological infrastructure that interprets signals from those organs. Moreover, certain characteristics of aerial habitat seem to defy common sense. That a habitat could be invisible or is capable of being present one moment and gone the next is far outside most personal and professional experiences. For example, the convective thermals used by raptors represent aerial habitats that are both invisible and highly ephemeral. Despite these limitations, extensions to our senses offered by access to the airspace though manned and unmanned aircraft and advances in remote sensing technology are beginning to reveal the intricacies of an ecological airspace (Helms et al. 2016; Bridge et al. 2011; Robinson et al. 2009).

\section{The Nature of Aerial Habitat}

The term "aerial habitat" has been used more in reference to plants than flying animals, specifically in relation to the phyllosphere where the ecology of epiphytes and other arboreal organisms plays out, usually high in the trees (e.g., Lindow and Brandl 2003). What constitutes aerial habitat in the context of aeroecology remains a somewhat open question. In atmospheric terms, aerial habitat includes those parts of the troposphere where aerobiological activity occurs, within the planetary boundary layer and lower parts of the free atmosphere (Davy et al. 2017). Typically, most activity occurs within the first several hundred meters above ground level. In biological terms, aerial habitat occurs when and where an organism's presence indicates use of an airborne resource (e.g., for food or as a movement corridor).

Many properties of the airspace give rise to variability in the structure of aerial habitat. These include wind speed and direction and their diverse manifestations (e.g., convection, shear, turbulence); various forms of moisture including humidity and cloud; precipitation; temperature; pressure and air density (see Chap. 2); magnetic and gravitational field strengths; odor; light conditions (e.g., polarized light, also Van Doren et al. 2017); and natural and anthropogenic gases, chemicals, and particulate matter. Other properties that may not be considered structural in relation to the airspace itself but are nonetheless influential include aerial predators and prey, topography, and anthropogenic structure (Lambertucci et al. 2015; Shipley et al. 2017). These characteristics influence the likelihood of occupancy for a given species within the occupiable airspace, which has vague upper and lower boundaries.

Animals occupying aerial habitats respond primarily to conditions aloft and are often behaviorally decoupled from land and water surfaces. However, at low altitudes, aerial habitat segues into terrestrial or aquatic habitat and animal behavior aloft is increasingly influenced by surface features. A large literature exists concerning the ecology of habitat interfaces, usually between patches of vegetation (Cadenasso et al. 2003). Where obvious transitions between the primary physical 
habitat types (land-water, land-air, air-water) have received some attention, the ecology of land-water interfaces dominates. Land-air and air-water interfaces are considered hard boundaries with comparatively abrupt transitions. Research on these boundaries focuses primarily on the physics and chemistry of gas exchange and microbial communities (Belnap et al. 2003) with little attention given to higher trophic levels. In these areas, the airspace may be a functional extension of surface terrestrial or aquatic habitat rather than aerial habitat per se, and time spent aloft by vertebrates and macroscopic invertebrates can be brief and usually occurs irrespective of conditions in the interstitial airspaces (e.g., nectar feeding bats, terrestrial territoriality in birds).

As altitude increases, conditions supporting buoyancy and powered flight diminish and the upper limit for a particular species is determined by the extent to which its behavior, anatomy, and physiology have adapted to decreasing air density, temperature, oxygen, and increasing radiation. Where these upper boundary conditions lie for most species is unknown owing to the difficulty of tracking small organisms. Winds are capable of lifting and dispersing invertebrates, seeds, and numerous microorganisms including pollen, spores, and fungi to altitudes exceeding 50 km (e.g., Drake and Reynolds 2012; Westbrook and Isard 1999; Womack et al. 2010). Among high-flying vertebrates, the bar-headed goose (Anser indicus) may be the most well-studied and most extreme. These geese routinely reach altitudes exceeding $6000 \mathrm{~m}$ when transiting the Himalayan Mountains of the Tibetan Plateau (Hawkes et al. 2011, 2013), although these geese and other species have been documented at higher altitudes, including a Ruppell's Vulture (Gyps rueppellii) which was struck by an aircraft at $>11,000 \mathrm{~m}$ (Laybourne 1974). At $6000 \mathrm{~m}$, air density and the partial pressure of oxygen is approximately half that at sea level under standard atmospheric conditions. Therefore, oxygen availability to power aerobic flight is considerably reduced just as the demands of flight increase as a result of reduced lift from low air density. Despite these constraints, bar-headed geese are not known to benefit from supportive winds in their trans-Himalayan migrations, instead relying on physiological adaptation to altitude and favoring calm atmospheric conditions (Hawkes et al. 2011).

\section{Ecology of the Airspace}

Terrestrial and aquatic habitats are home to a long list of ecological and behavioral processes including predation, competition, reproduction, and territoriality. The extent to which many of these processes are operational in the airspace is poorly known and, even if present, may be uncommon, ephemeral, or difficult to detect and observe. Certain behaviors are unambiguously at work including habitat selection, reproductive behavior, and predator-prey interactions. Others, especially those that partition resources such as exploitative competition and territoriality, even when operational, may be too short-lived or ambiguous to be useful.

Persistent resource defense territoriality generally occurs only when resources are defendable, limited, and predictable. In most cases, the energetic cost of 
occupying the airspace may be high relative to that in terrestrial and aquatic habitats as the airspace has no substrate and offers little unassisted buoyant support (at least for most vertebrates). Flying animals must power movement using their own energy reserves or by harvesting energy conveniently available from the wind (Sachs 2016; Pennycuick 1998), either of which limits the defendability of airborne resources. Also, most properties of the airspace that might serve as airborne resources (e.g., favorable wind, airborne invertebrates as food) may be both unpredictable and effectively unlimited at any given place and time. As a result, resource defense territoriality of airspaces is likely either uncommon or assumes an alternative form than that which has been previously recognized. For example, instead of defending a particular static area bounded in three dimensions, perhaps territoriality manifests as competition in space relative to other individuals (e.g., location in a flock or breeding swarm), which may be more spatially dynamic than the traditional view of a territory. Flying animals, particularly some invertebrates, do use the airspace to defend underlying terrestrial or aquatic habitats and their associated resources. We regard this use of airspace as an extension of surface territoriality as opposed to strict defense of an aerial resource.

Like other difficult-to-study habitats, the airspace offers a relatively unexplored context for examining the generality of ecological theory. If a given ecological process is present because the airspace and organism meet known criteria required for that process to be operational, then the durability of that concept is reinforced. Alternatively, an ecological process that is present despite the absence of expected criteria may call the generality of theory into question. Similar reasoning applies for ecological processes not present in the airspace. We discuss the occurrence of some of these ecological processes to emphasize the point that the airspace functions as habitat and that the ecology of the airspace in many ways differs little from the ecology of the land and the water.

\subsection{Habitat Quality, Use, and Selection}

Aerial habitats, like their terrestrial and aquatic counterparts, vary in quality in ways that influence survival and reproductive success (Jones 2001). Organisms react to this variation, although reactions differ among species. Microorganisms may be limited in their ability to "select" habitat, but distinct microbial communities exist in the airspace. Community composition is influenced by adjacent source terrestrial/aquatic habitats (Bowers et al. 2011; Brodie et al. 2007), weather (Harrison et al. 2005), and microhabitat differences in the airspace (Womack et al. 2010). Winds aerosolize microorganisms upward from the land (especially from plants; Vaïtilingom et al. 2012) or water and then can horizontally transport the larger microbes and pollen, sometimes for long distances (e.g., from the Sahara to the Alps; Meola et al. 2015), mixing communities. Once they have been passively dispersed, species differ in their ability to survive extreme temperature shifts, radiation, osmotic shocks, and desiccation (Joly et al. 2015), conditions that vary spatially and temporally (Womack et al. 2010). Eventually microorganisms return 
to earth due to wind drift, sedimentation, or precipitation (Deprés et al. 2012). Adaptations to the harsh life of the atmosphere (e.g., pigments to reduce the stress from radiation, cold shock proteins; Joly et al. 2015) have likely contributed to the successful inoculation of life in some of its most extreme aquatic and terrestrial habitats (e.g., polar ice sheets; Gonzalez-Toril et al. 2009).

In contrast to microorganisms' passive habitat use, flying animals often select habitats because they provide resources in support of some critical behavior such as foraging, reproduction, or migration. For example, migrating birds choose routes and weather conditions (e.g., Fig. 3.1) that allow them to manage the often conflicting goals of minimizing travel time, energy expenditure, and risk (Alerstam and Lindström 1990); these birds often respond to wind support more than temperature and humidity when selecting the routes and altitudes for their movements (Liechti et al. 2000). For instance, to assist their long-distance migrations over the ocean, bar-tailed godwits time departures from Alaska to coincide with weather likely to produce tailwinds (Gill et al. 2009). In contrast, some migratory insects choose their altitudes primarily based on atmospheric turbulence rather than tail wind assistance (Aralimarad et al. 2011). Diurnal soaring birds, such as the golden eagle, restrict their flight to a narrow band of low-altitude airspace as wind speeds increase (Lanzone et al. 2012). These and other forms of aerial habitat selection appear to be non-density dependent, since the resources being selected (e.g., favorable winds) are not thought to be limiting so as to create conditions for competitive exclusion.

A feature of habitat selection that distinguishes it from mere habitat use is that it results from the relationship between the costs and benefits of occupancy. For instance, during nocturnal migration, birds appear to select the lowest altitude where they first encounter supportive wind conditions even if "better" winds occur at higher altitudes (Mateos-Rodríguez and Liechti 2012). Presumably birds are unwilling to cross a cost barrier to seek out potentially more advantageous flying conditions suggesting that frequent altitude changes in search of optimal flying conditions may be costly (but see Bowlin et al. 2015).

\subsection{Reproduction}

The airspace provides many resources supporting reproduction, ranging from the concrete (space for asexual division, gamete dispersal, or copulation; protection from predators) to the abstract (a clear channel for communicating with potential mates). Many plants are pollinated through the action of the wind either directly or indirectly by affecting the flight paths of their pollinators. Bacteria have shorter reproductive cycles than their typical residency times in the air column and may have multiple generations between their ascents and descents (Burrows et al. 2009; Sattler et al. 2001).

Most aerial reproductive behavior in flying animals occurs among invertebrates. Insect mating swarms can take many forms. Under seasonally appropriate weather conditions, Diptera form highly localized mating swarms and may maintain 


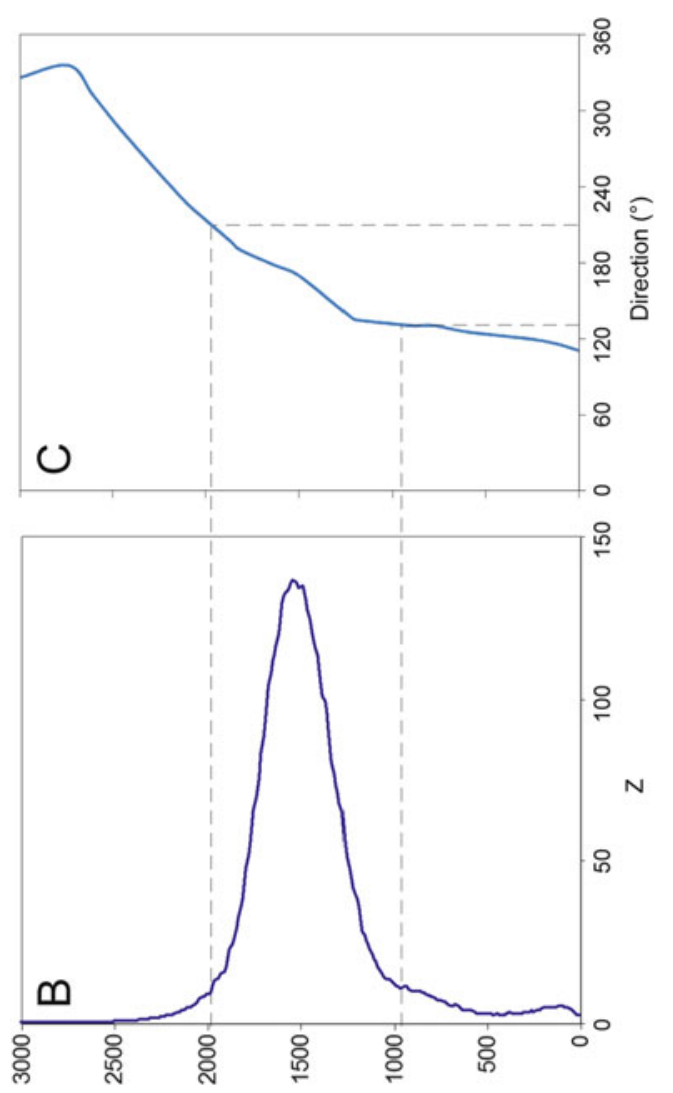

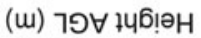

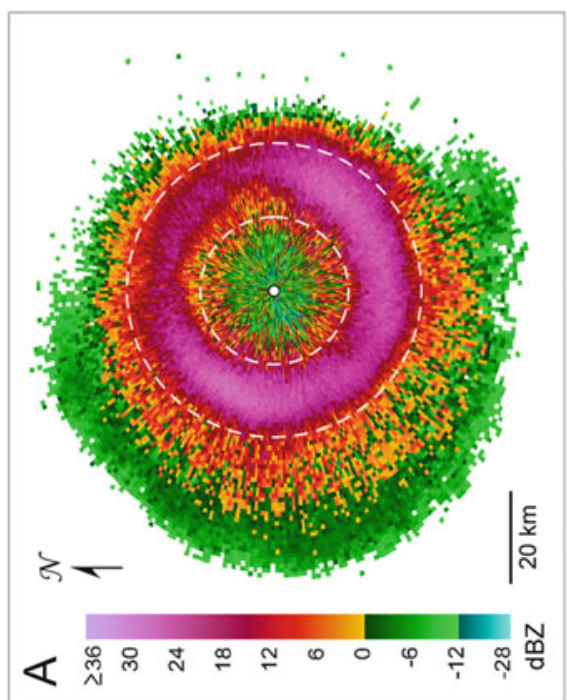

包宅范

를

त ส

ᄋํㅀ

츨

$\sum_{\text {i }}^{\infty}$

ธี ซี

(

氖

50

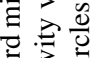

:

过

䨌

का

记

के च

ㅇํㅇㅇㅇㅇ

递志

출

死 吾交

o)

on $\cong 0$ के

3 远

은 응

छ

용

.

त न

己.

월

일

䒕 छ

$\circ$ 룡

'

च चु

늘 可

넝용

흉

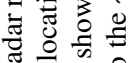

능

호웜

吾令范

3 के

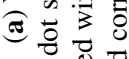

-

m. 

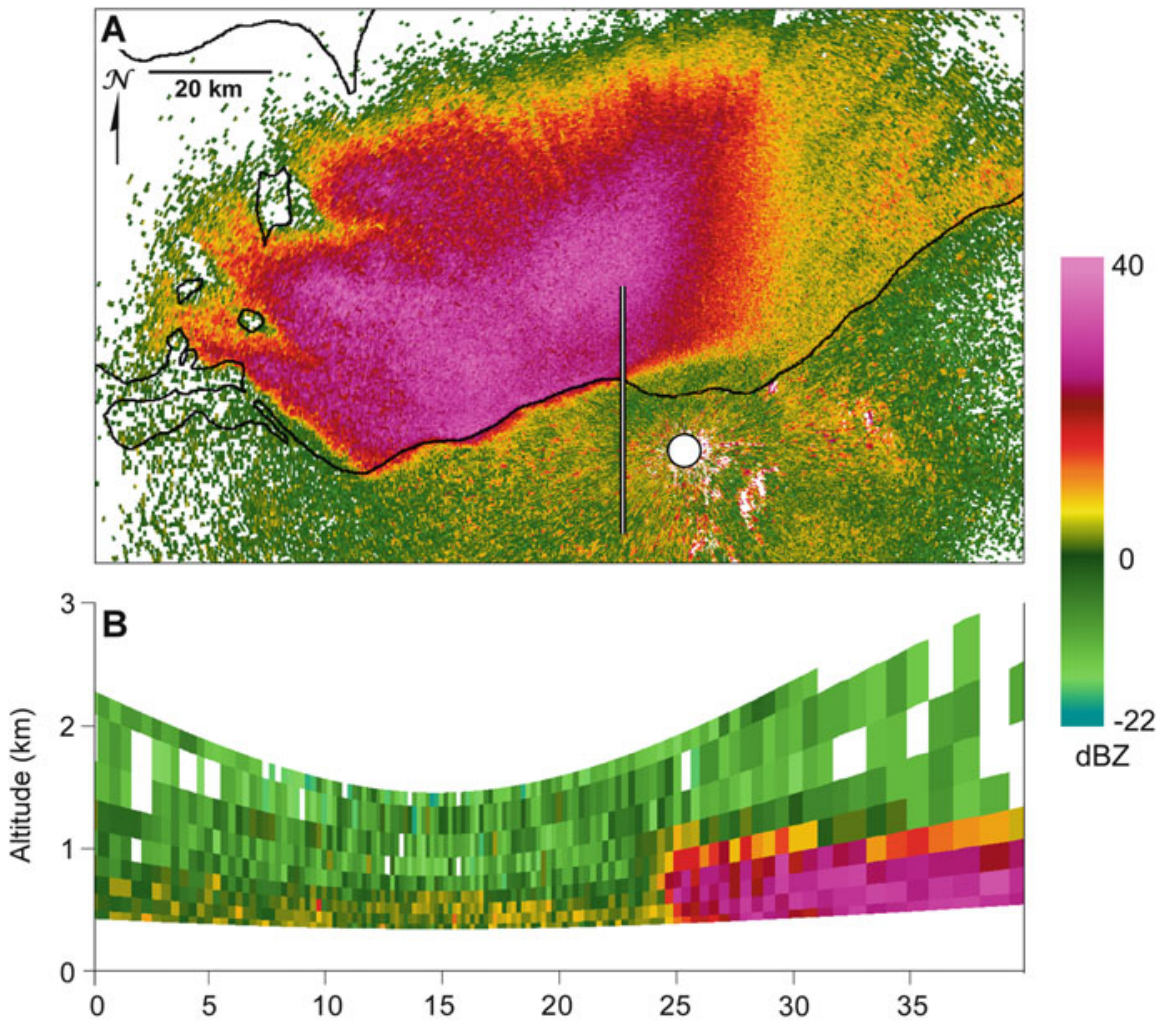

Transect distance, south to north $(\mathrm{km})$

Fig. 3.2 Emergence of Hexagenia mayflies from western Lake Erie on 18 June 2015, 2204 CST as captured by Cleveland, Ohio weather radar, KCLE (white dot). Radar reflectivities (dBZ) show varying mayfly densities aloft. The line segment in the upper image (a) west of the radar identifies the south-to-north cross section through the radar's volume scan shown below (b)

consistent locations with respect to conspicuous "swarm markers" in the landscape (e.g., a geographic feature or patch of sunlight; Sullivan 1981). Alternatively, mating swarms may occupy enormous areas (Dublon and Sumpter 2014). The mayfly swarming event depicted in Fig. 3.2 occupies more than $3000 \mathrm{~km}^{2}$ of Lake Erie's surface, at least $12 \%$ of its total area. Emergence generally occurs when both water temperatures exceed $20{ }^{\circ} \mathrm{C}$ (Corkum et al. 2006) and winds are moving toward the shore, as molting occurs on land after emergence; therefore, aerial habitat selection affects reproductive timing. Aerial reproductive swarming of this magnitude also serves as predator defense, as the massive pulse of food for local predators overwhelms the predator community to the point of satiation (Sweeney and Vannote 1982; but see Allan and Flecker 1989). Aerial copulation is common among invertebrates (e.g., Scott 1972; Allan and Flecker 1989), but appears to be rare among vertebrates. However, there is some evidence that red bats 
(Lasiurus borealis) and hoary bats (Lasiurus cinereus) copulate in flight (Cryan and Brown 2007).

The airspace is an important area for mating displays across taxa. Aerial lekking has been described for some insects (e.g., Lepidoptera, Andersson et al. 1998). Eusocial insects, particularly the Hymenoptera and Blattodea (e.g., termites), often make nuptial flights, although many of these occur close to the ground, where the role of the airspace may be limited (e.g., Dial and Vaughan 1987). Some bats may respond to turbulence when choosing mating display locations; this hypothesis has been suggested as an explanation for why bats congregate in the lee of wind turbines, a behavior which unfortunately often results in mortality (Cryan et al. 2014). Many birds have song flights and elaborate aerial displays, including the roding display of the Eurasian woodcock (Scolopax rusticola; Hoodless et al. 2008), the dive and shuttle of Anna's hummingbird (Calypte anna; Stiles 1982), and the sky dancing of the Montagu's harrier (Circus pygargus; Arroyo et al. 2013).

In addition to visual displays, many acoustic and olfactory breeding signals are transmitted through the air, including an assortment of vocalizations, stridulations, airborne pheromones, and pollinator attractors. Many of these signals evolved characteristics that allow them to travel efficiently through the air to receivers, taking forms that propagate with minimal degradation (Morton 1975). The signals themselves compete for airspace, or at least clear transmission through it, by varying in ways that minimize overlap within a community (Nelson and Marler 1990). This variation can either be an adaptive characteristic of a species- or population-specific signal (e.g., a distinct floral scent; Wright and Schiestl 2009) or the result of an individual modulating its signal in real time in response to current acoustic or olfactory "clutter" (e.g., modulating a bird song frequency to avoid overlap with noise; Goodwin and Podos 2013).

\subsection{Foraging, Competition, and Resource Partitioning}

The airspace supports considerable foraging habitat for many aerial specialists and obligate insectivores (e.g., swallows, flycatchers, insectivorous bats). Other flying animals depend upon predictable seasonal resource pulses (Yang et al. 2008). Usually these occur as the invertebrate mating swarms described above, but some aerial predators have adapted to exploit seasonal songbird migrations as a food source. The giant noctule bat (Nyctalus lasiopterus) will opportunistically switch diets to prey almost exclusively upon migrating songbirds (Popa-Lisseanu et al. 2007; Fukui et al. 2013). Eleonora's falcon (Falco eleonorae) also takes migrating songbirds in flight and appears to synchronize its reproduction with the seasonal availability of this food source (Wink and Ristow 2000). Similarly, peregrine falcons (Falco peregrinus) and red-tailed hawks (Buteo jamaicensis) hunt outside the large breeding colonies of insectivorous Brazilian free-tailed bats (Tadarida brasiliensis; Lee and Kuo 2001), which in turn prey on migrating noctuid moths. This sets up an aerial tritrophic interaction (raptors $>$ bats $>$ noctuid moths) that occurs each summer and is mediated by abiotic conditions in the airspace that 
determine the favorability of conditions for moth migration (McCracken et al. 2008).

Intra- and interspecific competition over aerial food resources also occurs in the airspace, although the difficulty in defending airborne resources together with limited niche overlap among competitors reduces the likelihood that such competition will arise (Mills 1986). Bats and common nighthawks (Chordeiles minor) have been observed in competitive interaction over insects at a human light source (Shields and Bildstein 1979). Altitudinal resource partitioning is hypothesized to explain differences in niche breadth among some avian aerial insectivores, wherein physical adaptations have allowed certain swift species to forage at higher altitudes and take advantage of larger and higher flying insects, thus reducing competition with swifts at lower altitudes (Collins 2015). Several species of desert bats differed in the locations and timing of foraging bouts over water sources in the Central Negev Highlands of Israel, suggestive of aerial resource partitioning due to competition for a shared insect resource (Razgour et al. 2011).

\section{$4 \quad$ Anthropogenic Impacts}

Even as human encroachment into the airspace advances, it is difficult to know whether certain taxa experience non-compensatory levels of mortality (Drewitt and Langston 2006; Kunz et al. 2007) which complicates how development of the airspace can be managed to reduce impacts to flying animal populations. In this context, recognizing the airspace as habitat may have meaningful consequences for species conservation and management. The habitat concept is necessarily central to international species-based environmental law (e.g., US Endangered Species Act and National Environmental Policy Act, EU's Habitats Directive and Birds Directive) and influences how biologists that work for regulatory agencies interpret the law in practice. That many parts of the airspace fall within the habitat concept could change the scope of application of these laws to include vast new areas. However, regulatory references to the airspace as habitat are scant; we could find only one and it argued against recognizing the airspace as habitat. In the context of a review of New Zealand's Resource Management Act which recognizes protection of significant habitats, Wallace (2007) specifically argues against characterizing flight corridors or migration routes as habitat because those areas are "disconnected from breeding and feeding spaces." Aside from being imprecise (many organisms do breed and feed in the airspace, even if the waterbirds considered by this Act do not), the point is also irrelevant since breeding and foraging are not required characteristics of habitat and are not the only habitat-related behaviors critical to survival (e.g., hibernating, roosting; Cryan and Veilleux 2007, Mehlman et al. 2005). Even if waterbirds were the only taxon of concern for a regulatory agency, they repeatedly travel similar routes between feeding and roosting locations (Everaert and Stienen 2007; Cox and Afton 1996), so any anthropogenic disruption in their path could have negative consequences on their populations by increasing mortality and decreasing reproductive success. Recognizing the airspace as habitat 
is critical for species conservation and management that consider entire life histories (Davy et al. 2017).

\subsection{Threats to Aerial Organisms}

The actions of society through development, commerce, transportation, policy, and resource extraction increasingly result in conflicts with flying animals that have impacts ranging from the safety of airline travel (Dolbeer and Wright 2008) to the price of corn (Boyles et al. 2011). The increasing construction of tall structures may result in long-term disruptions of aerial habitats, including wind turbines (Arnett et al. 2010); power lines (Martin 2011; Bevanger 1998); buildings, especially those using glass construction (Loss et al. 2014; Klem 1990); and some communications towers (Gehring et al. 2011; Gehring et al. 2009). One of the newest anthropogenic entrants to the airspace, unmanned aircraft systems (UAS), pose possible threats in that they may interfere with natural animal behavior and in other ways disrupt aerial ecosystems (e.g., Lambertucci et al. 2015). Current US federal guidelines allow UAS operations in all classes of airspace except those in the vicinity of airports (Class B; Federal Aviation Administration 2015a), but because proposed guidelines require operators to keep UAS within visual line-of-sight (Federal Aviation Administration 2015b), UAS use generally occurs relatively close to the ground within the region of most flying animal activity.

Anthropogenic development of the airspace creates novel challenges for flying animals, many of which are not adapted to flying in cluttered environments. Put another way, "perceptually [birds] have no prior for human artifacts such a buildings, power wires or wind turbines" (Martin 2011). In addition, not only may organisms lack the sensory capabilities to avoid development, but their senses may trick them into responding inappropriately to it. Ecological traps occur when rapid changes in the environment produce misleading cues about the quality of habitats. Based on these cues, organisms may select lower quality habitat which leads to lower survival or reproductive success, even though higher quality habitat may be available. Numerous examples of ecological traps have been documented for terrestrial habitats, and anthropogenic factors are usually responsible (Robertson and Hutto 2006; Schlaepfer et al. 2002). The airspace is no exception. Migrating birds drawn into circling illuminated communications towers, particularly those with guy wires, in low cloud conditions die in large numbers (Gehring et al. 2009; Larkin and Frase 1988). Under these conditions, airspace in the vicinity of lighted towers might be considered low-quality aerial habitat. Nonetheless, birds in these circumstances remain in flight, presumably because the hazy glow of a lighted tower in cloud is in some way attractive. Similarly, bats that die in the vicinity of wind turbines may select this aerial habitat, perhaps as a mating location or because turbines concentrate insects as food (Cryan et al. 2014).

Anthropogenic structures and machines in the airspace are not the only threat to aerial organisms. Chemicals and particulate matter as air pollutants also degrade aerial habitats, and the impacts of air pollution on animals in flight are poorly understood. Is the health of flying animals disproportionately affected owing to 
their relatively high metabolic rates during flight? Does air pollution interfere with olfactory or visual cues necessary for foraging, reproduction, and orientation? Might pollution that impacts aerial invertebrates have a trophic effect on their aerial predators? Does extreme air pollution impede visibility enough to increase risk of collisions with structure? Does pollution interfere with the composition and metabolic processes of aerial microbial communities in ways that affect climate and human health?

Anthropogenic structures that intrude upon aerial habitats can be designed, refitted, or adapted to limit their impacts on flying animals. Communications towers can be designed with lighting and structural support that reduces collision risk (Gehring et al. 2009). Curtailment of wind turbines has been shown to reduce bat mortality (Arnett et al. 2010), and current research is exploring ultraviolet (UV) illumination of turbines as a way of dissuading bats from approaching altogether (Gorresen et al. 2015). Combination camera/acoustic detection and deterrence systems are being explored as a means of reducing eagle mortality at wind facilities (Sinclair and DeGeorge 2016). A variety of markers are now available which increase the visibility of powerlines to birds in flight (e.g., Sporer et al. 2013). UV reflecting patterns on glass, which are visible to birds but not humans, may be effective at deterring birds from colliding with glass structure (Klem 2009).

Where technological deterrents are impractical or otherwise ineffective, the airspaces themselves may require protection. Airspace reserves may be needed to support the conservation of species as human development of aerial habitats continues and populations face compounding pressures across all phases of their life cycle (e.g., terrestrial habitat loss, mismatched phenology through climate change, predation and competition from nonnative species). Such reserves might focus on regulating development of the airspace near traditional movement corridors or in other areas where high densities of aerial organisms commonly occur or where species of concern are prone to fly (Diehl 2013; Lambertucci et al. 2015). Aerial reserves may be appropriate in areas where human-wildlife conflicts become a human safety concern or development presents a population-level risk to flying organisms or the ecological services they provide.

The preservation of aerial habitats may be quite different than traditional approaches for terrestrial and aquatic habitats. Most terrestrial and aquatic habitat preservation focuses on particular areas of concern and is intended to be continuous and long term, as disturbance can have lasting effects. In contrast, many humanwildlife conflicts are temporally dependent. Where animal use of aerial habitat is predictable, preservation may involve the timing of human activities rather than permanent restrictions on a particular area. For instance, proper lighting and curtailment of wind turbines when flying animals are most active can reduce or eliminate systematic impacts (Arnett et al. 2010; Duerr et al. 2012). Turbine curtailment could conceivably occur over even short timescales such as when fog or low cloud interferes with animals' ability to avoid structures (Kirsch et al. 2015). Many North American cities participate in seasonal lights-out programs, turning off the lights of large city buildings during peak bird migration times. These examples 
illustrate how anthropogenic hazards to flying animals can be reduced by timing the use of airspaces to complement animal phenology.

Brazilian free-tailed bats offer an interesting conservation case study. Brazilian free-tailed bats are migratory and roost during summer in caves across the southern tier of the continental USA, with exceptionally large concentrations in central Texas (Wilkins 1989). Bracken, Frio, and other caves in this region host summer maternity colonies containing millions of these bats; the colony in Bracken Cave is one of the largest single bat colonies in the world (McCracken 2003). In the evenings, they depart the caves en masse to forage on noctuid moths and other insects near the planetary boundary layer (Westbrook 2008; Fig. 3.3).

Conservation organizations acquired land to protect terrestrial habitat in the immediate vicinity of the cave entrance. Protecting these areas from human development indirectly offers overlying airspaces some associated protection by excluding potentially hazardous anthropogenic structures (e.g., wind turbines, communications towers) from the immediate area. Protection of Bracken Cave and its airspace preserves the phenomenon of mass exodus (sensu Brower and Malcolm 1991), the biological integrity of its populations (e.g., Allee effects, Langwig et al. 2015), the ecological services these bats provide to agriculture (Boyles et al. 2011; Davidai et al. 2015), and the educational opportunities afforded by these conspicuous movements (Pennisi et al. 2004). Even though Bracken and other caves in the region are occupied only half of the year (March through October), protecting the integrity of the cave itself from any form of development or even routine visitation is a year-round necessity as the cave represents a nonrenewable resource for bats. The immediate overlying airspace is also critical habitat as millions of bats transit this space when moving to and from foraging habitat. In contrast to the protection of the cave, aerial habitat in the vicinity of the cave could be considered renewable and its preservation seasonal.

The reserve concept is often oriented toward nonhuman species protection, but understanding and perhaps regulating airspace use with respect to flying animals has financial and human safety implications as well. From 1990 to 2007, bird strikes by civilian aircraft accounted for the overwhelming majority of monetary losses associated with wildlife strikes ( $\sim 125$ to $\sim \$ 625$ million annually in the USA) and resulted in 10 fatalities and 164 injuries (Dolbeer and Wright 2008). After US Airways Flight 1549 struck a flock of Canada Geese (Branta canadensis) and crash landed into the Hudson River, there were calls for improved monitoring of bird movements (Marra et al. 2009).

Bird-avoidance models exist that combine both historic and current data to identify times and places of increased risk of bird strikes for low-flying aircraft (Shamoun-Baranes et al. 2008). These warning systems forecast hazards using near real-time feedback from biological data collected from weather radar. However, classification algorithms designed to identify and extract biological data from weather radar data streams are rudimentary at best. Currently, no published algorithms exist that can differentiate among types of biological echoes (i.e., taxa) on weather radars, although some effort has been made to distinguish biological from nonbiological radar echoes (Park et al. 2009; Bachmann and Zrnić 2007). 
Fig. 3.3 Series of weather radar sweeps showing the evening exodus of Brazilian free-tailed bats from Frio Cave (yellow dot) near Concan, Texas, during the evening of 22 July 2014. The white dot shows the location of the weather radar (KDFX) at Laughlin AFB, Texas. Colors show differential phase, a radar polarimetry measure used here because it best distinguishes emerging bats (browns, yellows, and dark greens) from other radar bioscatterers (light green). The first four sweeps are separated by $10 \mathrm{~min}$; the fifth sweep occurred 30 min after the fourth and shows the movement more developed and bats emerging from other roosts in the vicinity

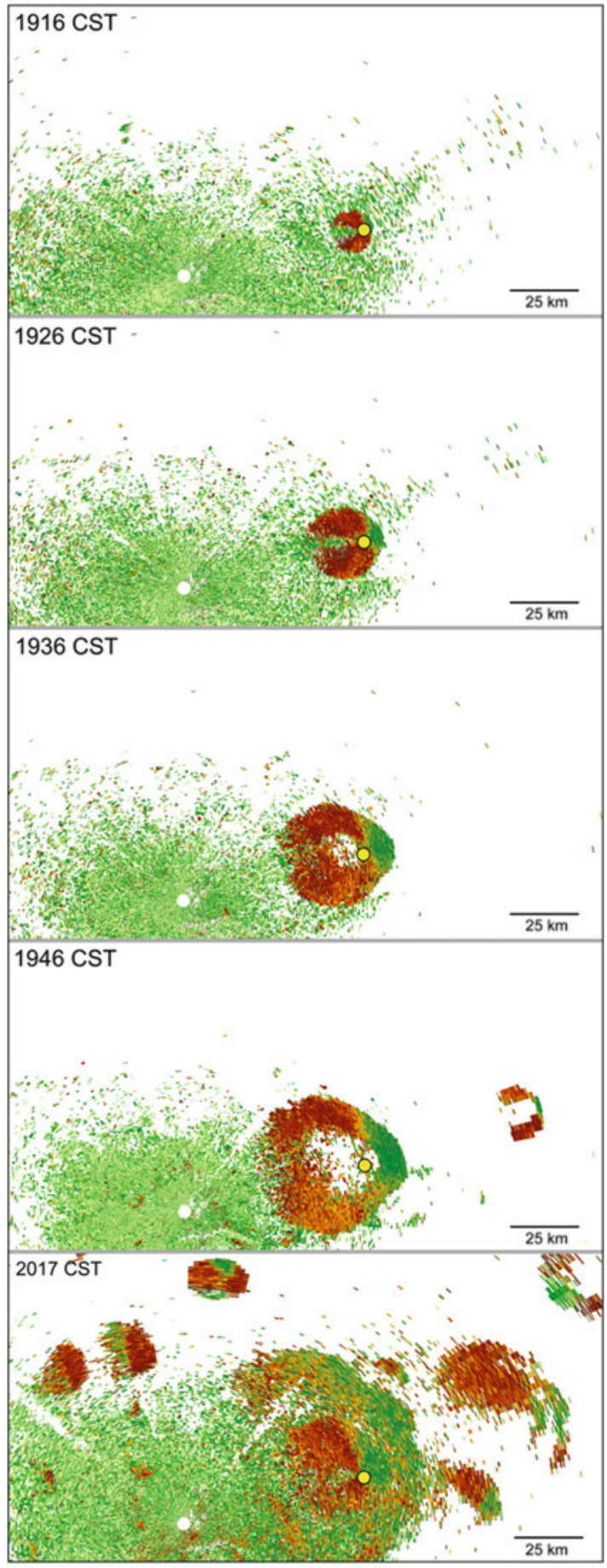


Identifying radar echoes to taxon is critical to the operational usefulness of any near real-time warning system, since large birds pose the greatest hazard to manned aircraft (Dolbeer and Wright 2008). Reliable information on the passage of large birds would enable responders to manage aircraft altitudes and approach and departure times and directions as needed. Figure 3.4 shows a typical autumn

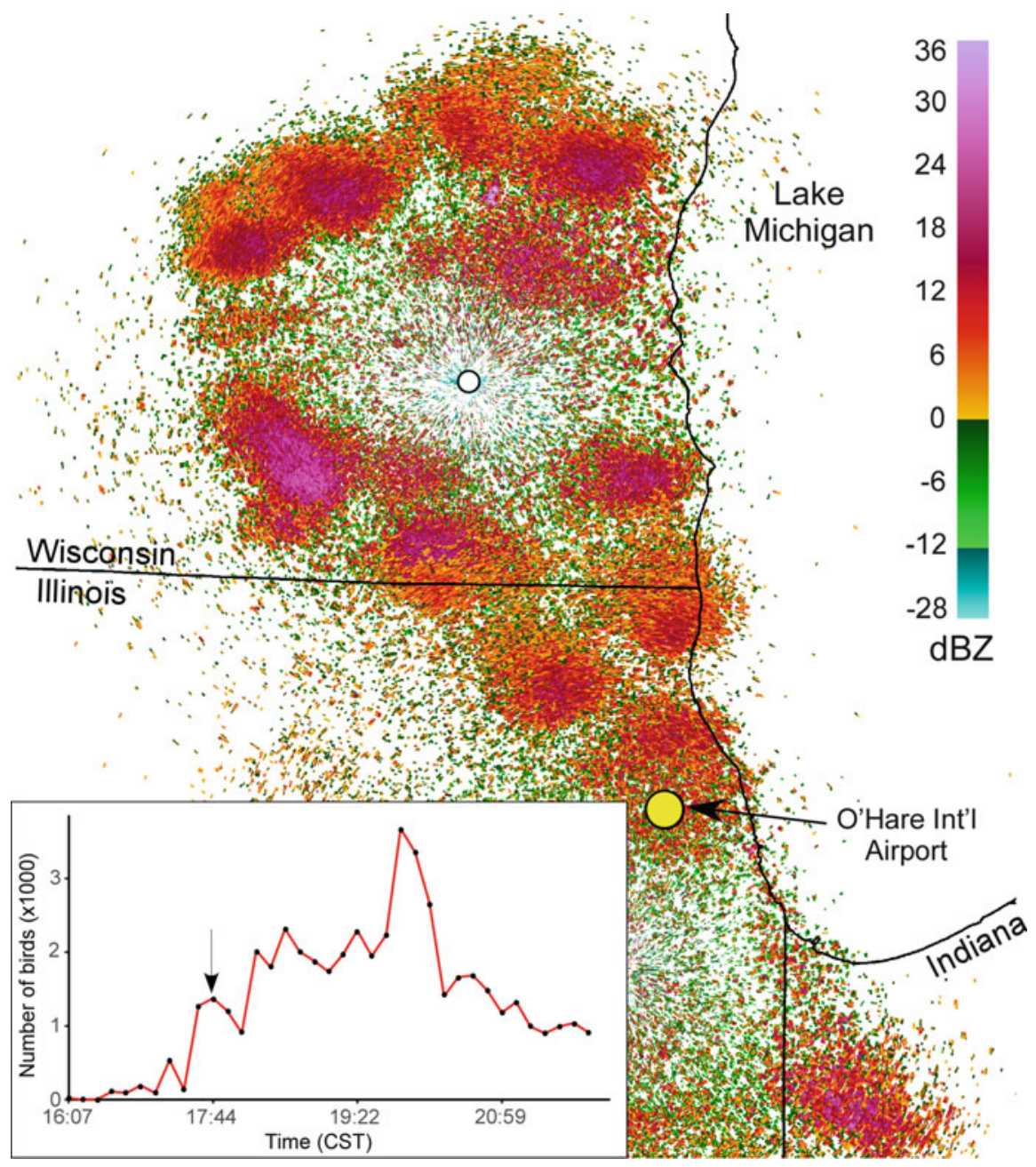

Fig. 3.4 Weather radars capture a moment during the onset of waterfowl migration toward the SSE across southeastern Wisconsin and northeastern Illinois on 22 Nov 2010, at 17:45 CST. A $10 \mathrm{~km}$ diameter airspace centered on O'Hare International Airport is represented by a yellow circle. The inset shows changes in the estimated number of birds within this circle as the migration begins and progresses. (The abundance calculation assumes mallard-sized birds for simplicity and because good estimates of radar cross section are available for Mallards (Anas platyrhynchos) to convert radar reflectivity to bird numbers (O'Neal et al. 2010; Chilson et al. 2012b); the likely presence of larger birds such as geese and perhaps some cranes reduces these estimates of bird abundances.). The arrow indicates when in the time series this radar capture occurred 
waterfowl migration toward the SSE with ducks, Canada Geese, and some Sandhill Cranes (Grus canadensis) departing habitats throughout southeastern Wisconsin and northeastern Illinois. Waves of waterfowl passed through the airspace of O'Hare International Airport, near Chicago, Illinois (Fig. 3.4, time series). In this image, the northern-most band of waterfowl radar echoes running west of the "Lake Michigan" label passed through O'Hare airspace at 19:50 and was responsible for the large pulse of waterfowl seen in the time series. These migratory pushes out of southeastern Wisconsin occur routinely each autumn, so during this time O'Hare becomes both heavily used commercial airspace and seasonally predictable waterfowl aerial habitat.

\section{$5 \quad$ Conclusions}

Definitions matter. How habitat is defined influences law, policy, and the actions of resource managers in interpreting policy. Frequent efforts to redefine habitat in ways that capture perceived shortcomings testify to the continuing importance of the habitat concept. The airspace easily satisfies widely recognized definitions of habitat and shares many ecological properties of other more familiar habitat types. Considering the airspace as habitat also encourages new perspectives on the habitat concept. For example, airspace lacks many of the familiar visible cues we associate with habitat such as vegetation, substrate, or topographic relief. The energetic costs of occupying aerial habitats are often high, and critical aerial resources can be simultaneously abundant, ephemeral, and unpredictable with respect to any one location. Identifying properties shared across all major habitat types-terrestrial, aquatic, and aerial—clarifies our understanding of habitat by focusing our attention on its most fundamental and essential elements.

Considering the airspace as habitat also reminds us that time as much as place is a critical component of habitat, since many of the airspace's resources for flying animals depend upon the weather and are therefore highly dynamic. Yet, many widely recognized definitions of habitat explicitly refer only to place and tend to reinforce a rather static notion of habitat (but see Dingle 2014; Southwood 1977). This conforms with human perception of habitats as generally stable through time, at least in the manner we are accustomed to instinctively experiencing them, even if academically, we might recognize that the suitability of nearly any habitat for a given species varies through time, often seasonally if not through ecological succession or some other biotic or abiotic process. In short, that habitat is "where one would go to find it" (Odum 1959) is no more important than when one would go to find it.

The habitat concept has proven to be influential in shaping and informing environmental law and natural resource management in many countries. It is unknown whether aerial habitat represents an expansion of the habitat concept that is applicable under existing law, for example, if the need should arise to create airspace reserves or otherwise regulate the airspace to ensure human safety or protect animal populations. Accelerating human occupancy and development of 
aerial habitats has created a greater need for regulation of the airspace, and clarification of the habitat concept is critical for developing or interpreting laws and regulatory practices that protect species when and where they are present.

We have much to learn about the ecology of the airspace. The dynamism of aerial habitat leads to dynamism of aeroecological processes generally, making them challenging to study, even with the aid of contemporary technology (Chilson et al. 2012a; Bridge et al. 2011). Recognizing that the airspace is habitat allows the known ecology of terrestrial and aquatic habitats to serve as models for predicting the conditions required for a wide range of ecological and behavioral processes to be operational in the airspace.

Acknowledgements We thank S. Soileau, H. Hoffmann, and the editors for helpful input on this chapter. The USGS Northern Rocky Mountain Science Center Ecolunch group provided valuable feedback as the concept of aerial habitat was developed. Any use of trade, product, or firm names is for descriptive purposes only and does not imply endorsement by the U.S. Government.

\section{References}

Alerstam T, Lindström A (1990) Optimal bird migration: the relative importance of time, energy, and safety. In: Gwinner E (ed) Bird migration. Springer, Berlin, pp 331-351

Allan JD, Flecker AS (1989) The mating biology of a mass-swarming mayfly. Anim Behav 37: 361-371

Andersson S, Rydell J, Swensson GE (1998) Light, predation and the lekking behavior of the ghost swift Hepialus humuli (L.) (Lepidoptera: Hepialidae). Proc R Soc Lond B 264:1345-1351

Aralimarad P, Reynolds AM, Lim KS, Reynolds DR, Chapman JW (2011) Flight altitude selection increases orientation performance in high-flying nocturnal insect migrants. Anim Behav 82: $1221-1225$

Arnett EB, Huso MM, Schirmacher MR, Hayes JP (2010) Altering turbine speed reduces bat mortality at wind-energy facilities. Front Ecol Environ 9:209-214

Arroyo B, Mougeot F, Bretagnolle V (2013) Characteristics and sexual functions of sky-dancing displays in a semi-colonial raptor, the Montagu's Harrier (Circus Pygargus). J Raptor Res 47: $185-196$

Bachmann S, Zrnić DS (2007) Spectral density of polarimetric variables separating biological scatterers in the VAD display. J Atmos Ocean Technol 24:1186-1198

Belnap J, Hawkes CV, Firestone MK (2003) Boundaries in miniature: two examples from soil. Bioscience 53:739-749

Bevanger K (1998) Biological and conservation aspects of bird mortality caused by electricity power lines: a review. Biol Conserv 86:67-76

Bowers RM, McLetchie S, Knight R, Fierer N (2011) Spatial variability in airborne bacterial communities across land-use types and their relationship to the bacterial communities of potential source environments. ISME J 5:601-612

Bowlin MS, Enstrom DA, Murphy BJ, Plaza E, Jurich P, Cochran J (2015) Unexplained altitude changes in a migrating thrush: Long-flight altitude data from radio-telemetry. Auk 132: 808-816

Boyles JG, Cryan PM, McCracken GF, Kunz TH (2011) Economic importance of bats in agriculture. Science 332:41-42 
Bridge ES, Thorup K, Bowlin MS, Chilson PB, Diehl RH, Fleron RW, Hartl P, Kays R, Kelly JF, Robinson WD, Wikelski M (2011) Technology on the move: recent and forthcoming innovations for tracking migratory birds. Bioscience 61:689-698

Brodie EL, DeSantis TZ, Parker JPM, Zubietta IX, Piceno YM, Andersen GL (2007) Urban aerosols harbor diverse and dynamic bacterial populations. Proc Natl Acad Sci 104:299-304

Brower LP, Malcolm SB (1991) Animal migrations: endangered phenomena. Am Zool 31: 265-276

Burrows SM, Elbert W, Lawrence MG, Pöschl U (2009) Bacteria in the global atmosphere-Part 1: review and synthesis of literature data for different ecosystems. Atmos Chem Phys 9: 9263-9280

Cadenasso ML, Pickett STA, Weathers KC, Bell SS, Benning TL, Carreiro MM, Dawson TE (2003) An interdisciplinary and synthetic approach to ecological boundaries. Bioscience 53: $717-722$

Chilson PB, Frick WF, Kelly JF, Howard KW, Larkin RP, Diehl RH, Westbrook JK, Kelly TA, Kunz TH (2012a) Partly cloudy with a chance of migration: weather, radars, and aeroecology. Bull Am Meteorol Soc 93:669-686

Chilson PB, Frick WF, Stepanian PM, Shipley JR, Kunz TH, Kelly JK (2012b) Estimating animal densities in the aerosphere using weather radar: To $\mathrm{Z}$ or not to $\mathrm{Z}$ ? Ecosphere 3:72

Collins CT (2015) Food habits and resource partitioning in a guild of Neotropical swifts. Wilson J Ornithol 127:239-248

Corkum LD, Ciborowski JJH, Dolan DM (2006) Timing of Hexagenia (Ephemeridae: Ephemeroptera) mayfly swarms. Can J Zool 84:1616-1622

Cox RR, Afton AD (1996) Evening flights of female northern pintails from a major roost site. Condor 89:810-819

Cryan PM, Brown AC (2007) Migration of bats past a remote island offers clues toward the problem of bat fatalities at wind turbines. Biol Conserv 139:1-11

Cryan PM, Veilleux JP (2007) Migration and use of autumn, winter, and spring roosts by tree bats. In: Lacki MJ, Hayes HJP, Kurta A (eds) Bats in forests: conservation and management. The Johns Hopkins University Press, Baltimore, pp 153-175

Cryan PM, Gorrensen PM, Hein CD, Schirmacher MR, Diehl RH, Huso MM, Hayman DTS, Fricker PD, Bonaccorso FJ, Johnson DH, Heist K, Dalton DC (2014) Behavior of bats at wind turbines. PNAS 111:15126-15131

Davidai N, Westbrook JK, Lessard J, Hallam TG, McCracken GF (2015) The importance of natural habitats to Brazilian free-tailed bats in intensive agricultural landscapes in the Winter Garden region of Texas, United States. Biol Conserv 190:107-114

Davy CM, Ford AT, Fraser KC (2017) Aeroconservation for the fragmented skies. Conserv Lett. https://doi.org/10.1111/conl.12347

Dennis RLH, Shreeve TG, Van Dyck H (2003) Towards a functional resource-based concept of habitat: a butterfly biology viewpoint. Oikos 102:417-426

Dennis RLH, Shreeve TG, van Dyck H (2006) Habitats and resources: the need for a resourcebased definition to conserve butterflies. Biodivers Conserv 15:1943-1966

Deprés VR, Huffman JA, Burrows SM, Hoose C, Safatov AS, Buryak G, Fröhlich-Nowoisky J, Elbert W, Andreae MO, Pöschl U, Jaenicke R (2012) Primary biological aerosol particles in the atmosphere: a review. Tellus B 64. https://doi.org/10.3402/tellusb.v64i0.15598

Dial KP, Vaughan TA (1987) Opportunistic predation on alate termites in Kenya. Biotropica 19: 185-187

Diehl RH (2013) The airspace is habitat. Trends Ecol Evol 28:377-379

Dingle H (2014) Migration: the biology of life on the move, 2nd edn. Oxford University Press, Oxford

Dolbeer RA, Wright S (2008) Wildlife strikes to civil aircraft in the United States 1990-2007. Bird Strike Committee Proceedings 
Drake VA, Reynolds DR (2012) Radar entomology: observing insect flight and migration. CABI, Wallingford

Drewitt AL, Langston RHW (2006) Assessing the impacts of wind farms on birds. Ibis 148:29-42

Dublon IAN, Sumpter DJT (2014) Flying insect swarms. Curr Biol 24:R828-R830

Duerr AE, Miller TA, Lanzone M, Brandes D, Cooper J, O’Malley K, Maisonneuve C, Tremblay J, Katzner $\mathrm{T}$ (2012) Testing an emerging paradigm in migration ecology shows surprising differences in efficiency between flight modes. PLoS One 7:e35548. https://doi.org/10.1371/ journal.pone. 0035548

Elton CS (1966) The pattern of animal communities. Chapman and Hall, London

Everaert J, Stienen EWM (2007) Impact of wind turbines on birds in Zeebrugge (Belgium): significant effect on breeding tern colony due to collisions. Biodivers Conserv 16:3345-3359

Federal Aviation Administration (2015a) Notice JO 7210.882. Unmanned aircraft operations in the national airspace system (NAS)

Federal Aviation Administration (2015b) 14 CFR Chapter I. Clarification of the applicability of aircraft registration requirements for unmanned aircraft systems (UAS) and request for information regarding electronic registration for UAS

Fukui D, Dewa H, Katsuta S, Sato A (2013) Bird predation by the birdlike noctule in Japan. J Mammal 94:657-661

Gehring J, Kerlinger P, Manville AM (2009) Communication towers, lights, and birds: successful methods of reducing the frequency of avian collisions. Ecol Appl 19:505-514

Gehring JL, Kerlinger P, Manville AM (2011) The role of tower height and guy wires on avian collisions with communication towers. J Wildl Manage 75:848-855

Gill RE Jr, Tibbitts TL, Douglas DC, Handel CM, Mulcahy DM, Gottschalck JC, Warnock N, McCaffery BJ, Battley PF, Piersma T (2009) Extreme endurance flights by landbirds crossing the Pacific Ocean: ecological corridor rather than barrier? Proc R Soc Lond B 276:447-457

Gonzalez-Toril E, Amils R, Delmas RJ, Petit J-R, Komarek J, Elster J (2009) Bacterial diversity of autotrophic enriched cultures from remote, glacial Antarctic, Alpine and Andean aerosol, snow and soil samples. Biogeosciences 6:33-44

Goodwin SE, Podos J (2013) Shift of song frequencies in response to masking tones. Anim Behav 85:435-440

Gorresen PM, Cryan PM, Dalton DC, Wolf S, Johnson JA, Todd CM, Bonaccorso FJ (2015) Dim ultraviolet light as a means of deterring activity by the Hawaiian hoary bat Lasiurus cinereus semotus. Endanger Species Res 28:249-257

Hall LS, Krausman PR, Morrison ML (1997) The habitat concept and a plea for a standard terminology. Wildl Soc Bull 25:173-182

Harrison RM, Jones AM, Biggins PD, Pomeroy N, Cox CS, Kidd SP, Hobman JL, Brown NL, Beswick A (2005) Climate factors influencing bacterial count in background air samples. Int J Biometeorol 49:167-178

Hawkes LA, Balachandran S, Batbayar N, Butler PJ, Frappell PB, Milsom WK, Tseveenmyadag N, Newman SH, Scott GR, Sathiyaselvam P, Takekawa JY, Wikelski M, Bishop CM (2011) The trans-Himalayan flights of bar-headed geese (Anser indicus). Proc Natl Acad Sci 108:9516-9519

Hawkes LA, Balachandran S, Batbayar N, Butler PJ, Chua B, Douglas DC, Frappell PB, Hou Y, Milsom WK, Newman SH, Prosser DJ, Sathiyaselvam P, Scott GR, Takekawa JY, Natsagdorj T, Wikelski M, Witt MJ, Yan B, Bishop CM (2013) The paradox of extreme high-altitude migration in bar-headed geese Anser indicus. Proc R Soc Lond B: Biol Sci 280. https://doi.org/10.1098/rspb.2012.2114

Hedenström A, Norevik G, Warfvinge K, Anderson A, Bäckman J, Åkesson S (2016) Annual 10-month aerial life phase in the common swift Apus apus. Curr Biol 26. https://doi.org/10. 1016/j.cub.2016.1009.1014

Helms JA, Godfrey AP, Ames T, Bridge ES (2016) Predator foraging altitudes reveal the structure of aerial insect communities. Sci Rep 6:28670. https://doi.org/10.1038/srep28670

Hoodless AN, Inglis JG, Doucet J-P, Aebischer NJ (2008) Vocal individuality in the roding calls of woodcock Scolopax rusticola and their use to validate a survey method. Ibis 150:80-89 
Jaenike J, Holt RD (1991) Genetic variation for habitat preference: evidence and explanations. Am Nat 137:S67-S90

Joly M, Amato P, Sancelme M, Vinatier V, Abrantes M, Deguilluame L, Delort A-M (2015) Survival of microbial isolates from clouds towards simulated atmospheric stress factors. Atmos Environ 117:92-98

Jones J (2001) Habitat selection studies in avian ecology: a critical review. Auk 118:557-562

Kirsch EM, Wellik MJ, Suarez M, Diehl RH, Lutes J, Woyczik W, Krapfl J, Sojda R (2015) Observation of sandhill cranes' (Grus canadensis) flight behavior in heavy fog. Wilson J Ornithol 127:281-288

Klem D Jr (1990) Collisions between birds and windows: mortality and prevention. J Field Ornithol 61:120-130

Klem D Jr (2009) Avian mortality at windows: the second largest human source of bird mortality on Earth. Tundra to tropics: connecting birds, habitats and people. In: Proceedings of the 4th international partners in flight conference: Tundra to Tropics. USDA, Forest Service, McAllen, Texas, pp 244-251

Kunz TH, Arnett EB, Erickson WP, Hoar AR, Johnson GD, Larkin RP, Strickland MD, Thresher RW, Tuttle MD (2007) Ecological impacts of wind energy development on bats: questions, research, needs, and hypotheses. Front Ecol Environ 5:315-324

Kunz TH, Gauthreaux SA Jr, Hristov NI, Horn JW, Jones G, Kalko EK, Larkin RP, McCracken GF, Swartz SM, Srygley RB, Dudley R, Westbrook JK, Wikelski M (2008) Aeroecology: probing and modeling the aerosphere. Integr Comp Biol 48:1-11

Lambertucci SA, Shepard ELC, Wilson RP (2015) Human-wildlife conflicts in a crowded airspace. Science 348:502-504

Langwig KE, Frick WF, Reynolds R, Parise KL, Drees KP, Hoyt JR, Cheng TL, Kunz TH, Foster JT, Kilpatrick AM (2015) Host and pathogen ecology drive the seasonal dynamics of a fungal disease, white-nose syndrome. Proc R Soc Lond B: Biol Sci 282. https://doi.org/10.1098/rspb. 2014.2335

Lanzone M, Miller TA, Turk P, Brandes D, Halverson C, Maisonneuve C, Tremblay J, Cooper J, O'Malley K, Brooks RP, Katzner T (2012) Flight responses by a migratory soaring raptor to changing meteorological conditions. Biol Lett 8:710-713

Larkin RP, Frase BA (1988) Circular paths of birds flying near a broadcasting tower in cloud. J Comp Psychol 102:90-93

Laybourne RC (1974) Collision between a vulture and an aircraft at an altitude of 37,000 feet. Wilson Bull 86:461-462

Lee Y, Kuo Y (2001) Predation on Mexican free-tailed bats by peregrine falcons and red-tailed hawks. J Raptor Res 35:115-123

Liechti F, Klaasen M, Bruderer B (2000) Predicting migratory flight altitudes by physiological migration models. Auk 117:205-214

Liechti F, Witvliet W, Weber R, Bachler E (2013) First evidence of a 200-day non-stop flight in a bird. Nat Commun 4. https://doi.org/10.1038/ncomms3554

Lindow S, Brandl M (2003) Microbiology of the phyllosphere. Appl Environ Microbiol 69: $1875-1883$

Linnæus C (1754) Genera plantarum, 5th edn

Loss SR, Will T, Loss SS, Marra PP (2014) Bird-building collisions in the United States: estimates of annual mortality and species vulnerability. Condor: Ornithol Appl 116:8-23

Marra PP, Dove CJ, Dolbeer RA, Dahlan N, Heacker M, Whatton J, Diggs N, France C, Henkes G (2009) Migratory Canada geese cause crash of US Airways Flight 1549. Front Ecol Environ 7:297-301

Martin GR (2011) Understanding bird collisions with man-made objects: a sensory ecology approach. Ibis 153:239-254

Mateos-Rodríguez M, Liechti F (2012) How do diurnal long-distance migrants select flight altitude in relation to wind? Behav Ecol 23:403-409 
McCracken GF (2003) Estimates of population sizes in summer colonies of Brazilian free-tailed bats (Tadarida brasiliensis). Monitoring trends in bat populations of the US and territories: problems and prospects. In: O'Shea TJ, Bogan MA (eds) US geological survey, biological resources discipline, information and technology report, USGS/BRD/ITR-2003-003, 21-30

McCracken GF, Gillam EH, Westbrook JK, Lee Y, Jensen ML, Balsley BB (2008) Brazilian freetailed bats (Tadarida brasiliensis: Molossidae, Chiroptera) at high altitude: links to migratory insect populations. Integr Comp Biol 48:107-118

Mehlman DW, Mabey SE, Ewert DN, Duncan C, Abel B, Cimprich DA, Sutter RD, Woodrey MS (2005) Conserving stopover sites for forest-dwelling migratory landbirds. Auk 122:1281-1290

Meola M, Lazzaro A, Zeyer J (2015) Bacterial composition and survival on Sahara dust particles transported to the European Alps. Front Microbiol 6:1454

Mills AM (1986) The influence of moonlight on the behavior of goatsuckers (Caprimulgidae). Auk 103:370-378

Morrison ML, Marcot BG, Mannan RW (2006) Wildlife-habitat relationships: concepts and applications, 3rd edn. Island Press, Washington, DC

Morton ES (1975) Ecological sources of selection on avian sounds. Am Nat 109:17-34

Nelson DA, Marler P (1990) The perception of birdsong and an ecological concept of signal space. In: Stebbins WC, Berkley MA (eds) Comparative perception, Complex signals, vol 2. Wiley, New York, pp 443-478

O'Neal BJ, Stafford JD, Larkin RP (2010) Waterfowl on weather radar: applying ground-truth to classify and quantify bird movements. J Field Ornithol 81:71-82

Odum EP (1959) Fundamentals of ecology, 2nd edn. W. B. Saunders, Philadelphia

Park H, Ryzhkov AV, Zrnic DS, Kim K-E (2009) The hydrometeor classification algorithm for the polarimetric WSR-88D: description and application to an MCS. Weather Forecast 24:730-748

Pennisi LA, Holland SM, Stein TV (2004) Achieving bat conservation through tourism. J Ecotour 3:195-207

Pennycuick CJ (1998) Field observations of thermals and thermal streets, and the theory of crosscountry soaring flight. J Avian Biol 29:33-43

Popa-Lisseanu AG, Delgado-Huertas A, Forero MG, Rodríguez A, Arlettaz R, Ibáňez C (2007) Bats' conquest of a formidable foraging niche: the myriads of nocturnally migrating songbirds. PLoS One 2. https://doi.org/10.1371/journal.pone.0000205

Razgour O, Korine C, Saltz D (2011) Does interspecific competition drive patterns of habitat use in desert bat communities? Oecologia 167:493-502

Robertson BA, Hutto RL (2006) A framework for understanding ecological traps and an evaluation of the existing evidence. Ecology 87:1075-1085

Robinson WDBM, Bisson IA, Shamoun-Baranes J, Thorup K, Diehl RH, Kunz TH, Mabey SE, Winkler DW (2009) Integrating concepts and technologies at the frontiers of bird migration. Front Ecol Environ 8:354-361

Sachs G (2016) In-flight measurement of upwind dynamic soaring in albatrosses. Prog Oceanogr. https://doi.org/10.1016/j.pocean.2016.01.003

Sattler B, Puxbaum H, Psenner R (2001) Bacterial growth in supercooled cloud droplets. Geophys Res Lett 28:239-242

Schlaepfer MA, Runge MC, Sherman PW (2002) Ecological and evolutionary traps. Trends Ecol Evol 17:474-480

Scott JA (1972) Mating of butterflies. J Res Lepid 11:99-127

Shamoun-Baranes J, Bouten W, Buurma L, Defusco RP, Dekker A, Sierdsema H, Sluiter F, van Belle J, van Gasteren H, van Loon E (2008) Avian information systems: developing web-based bird avoidance models. Ecol Soc 13:38

Shields WM, Bildstein KL (1979) Birds versus bats: behavioral interactions at a localized food source. Ecology 60:468-474

Shipley JR, Kelly JF, Frick WF (2017) Toward integrating citizen science and radar data for migrant bird conservation. Remote Sens Ecol Conserv. https://doi.org/10.1002/rse2.62 
Sinclair K, DeGeorge E (2016) Wind energy industry eagle detection and deterrents: research gaps and solutions workshop summary report. National Renewable Energy Laboratory, Golden, CO, Technical report NREL/TP-5000-65735

Southwood TRE (1977) Habitat, the templet for Ecological strategies? J Anim Ecol 46:337-365

Sporer MK, Dwyer JF, Gerber BD, Harness RE, Pandey AK (2013) Marking power lines to reduce avian collision near the Audubon National Wildlife Refuge, North Dakota. Wildl Soc Bull. https://doi.org/10.1002/wsb.329

Stiles FG (1982) Aggressive and courtship displays of the male Anna's hummingbird. Condor 84: 208-225

Sullivan R (1981) Insect swarming and mating. Fla Entomol 64:44-65

Sweeney BW, Vannote RL (1982) Population synchrony in mayflies: a predation satiation hypothesis. Evolution 36:810-821

Vaïtilingom M, Attard E, Gaiani N, Sancelme M, Deguillaume L, Flossmann AI, Amato P, Delort AM (2012) Long-term features of cloud microbiology at the puy de Dôme (France). Atmos Environ 56:88-100

Van Doren BM, Horton KG, Dokter AM, Klinck H, Elbin SB, Farnsworth A (2017) High-intensity urban light installation dramatically alters nocturnal bird migration. PNAS 114:11175-11180

Wallace P (2007) The nature of habitat. NZ J Environ Law 11:211-240

Westbrook JK (2008) Noctuid migration in Texas within the nocturnal aeroecological boundary layer. Integr Comp Biol 48:99-106

Westbrook JK, Isard SA (1999) Atmospheric scales of biotic dispersal. Agric For Meteorol 97: 263-274

Wilkins KT (1989) Tadarida brasiliensis. In: Best TL, Anderson S (eds) Mammalian species, no 331. American Society of Mammalogists, pp 1-10

Wink M, Ristow D (2000) Biology and molecular genetics of Eleonora's falcon (Falco eleonorae), a colonial raptor of Mediterranean Islands. In: Chancellor, Meyburg (eds) Raptors at risk. Hancock House, Blaine, pp 653-668

Womack AM, Bohannan BJM, Green JL (2010) Biodiversity and biogeography of the atmosphere. Philos Trans R Soc Lond B 365:3645-3653

Wright GA, Schiestl FP (2009) The evolution of floral scent: the influence of olfactory learning by insect pollinators on the honest signaling of floral rewards. Funct Ecol 23:841-851

Yang LH, Bastow JL, Spence KO, Wright AN (2008) What can we learn from resource pulses. Ecology 89:621-634 